\section{Persontilpassede måltider}

Individuelle menyer basert på individuelle helseopplysninger kan senke risikoen for hyperglykemi etter måltid.

Hyperglykemi øker risikoen for utvikling av type 2-diabetes, men glykemisk indeks for enkle matvarer kan ikke forutsi blodsukkerstigningen etter sammensatte måltider.

I en studie med 800 forsøkspersoner som var representative for en «frisk» befolkning, ble det samlet inn alt $i$ alt enorme mengder persondata for å minimalisere blodsukkerstigningen etter måltider (1). Personene ble utstyrt med blodsukkermåler under huden, som målte glukosenivået kontinuerlig. Blodsukkerdataene ble sammenholdt med data fra blodanalyser, bl.a. glykosylert hemoglobin, bakteriesammensetning i tarm, personlige forhold som fysisk aktivitet, foruten matinntak i forsøksuken - alt via en app på smarttelefoner. Forsøkspersonene spiste en kombinasjon av standardiserte og egenvalgte måltider. Basert på disse dataene ble det utarbeidet en algoritme som så ble validert på en ny 100-personers kohort.

Det var en signifikant korrelasjon mellom algoritmebasert prediksjon og målte blodsukkerverdier. I et blindet, randomisert diettforsøk kunne algoritmen foreskrive individualiserte dietter minst like godt som en ernæringsspesialist. En persontilpasset diett basert på algoritmen ga i løpet av forsøksuken endret tarmflora.

- Denne studien er meget omfattende og viser tydelig at responsen på samme diett varierer fra person til person, sier professor Harald Carlsen ved Institutt for kjemi, bioteknologi og matvitenskap, Norges miljøog biovitenskapelige universitet. - Den treffsikre prediksjonen gitt av den maskinlærte algoritmen tyder på at forskerne hadde valgt gode kliniske og biokjemiske markører for forsøkspersonene, sier Carlsen, som antar at nye algoritmer og raffinering av denne studien vil følge.

- Det blir spennende å se om nye studier vil gi samme presise og individuelle kostråd også for andre tilstander, slik som forhøyet kolesterolnivå, og avdekke hvilke faktorer som er mest bestemmende for individuelle forskjeller, sier Carlsen.

\section{Haakon B. Benestad \\ h.b.benestad@medisin.uio.no \\ Universitetet i Oslo}

\section{Litteratur}

1. Zeevi D, Korem T, Zmora N et al. Personalized nutrition by prediction of glycemic responses. Cell 2015; 163: 1079-94.

\title{
Smittespredning av zikavirus
}

\author{
Zikaviruset, som til nå har vært lite studert, kan være forklaringen \\ på markant økt forekomst av mikrokefali hos nyfødte i Brasil.
}

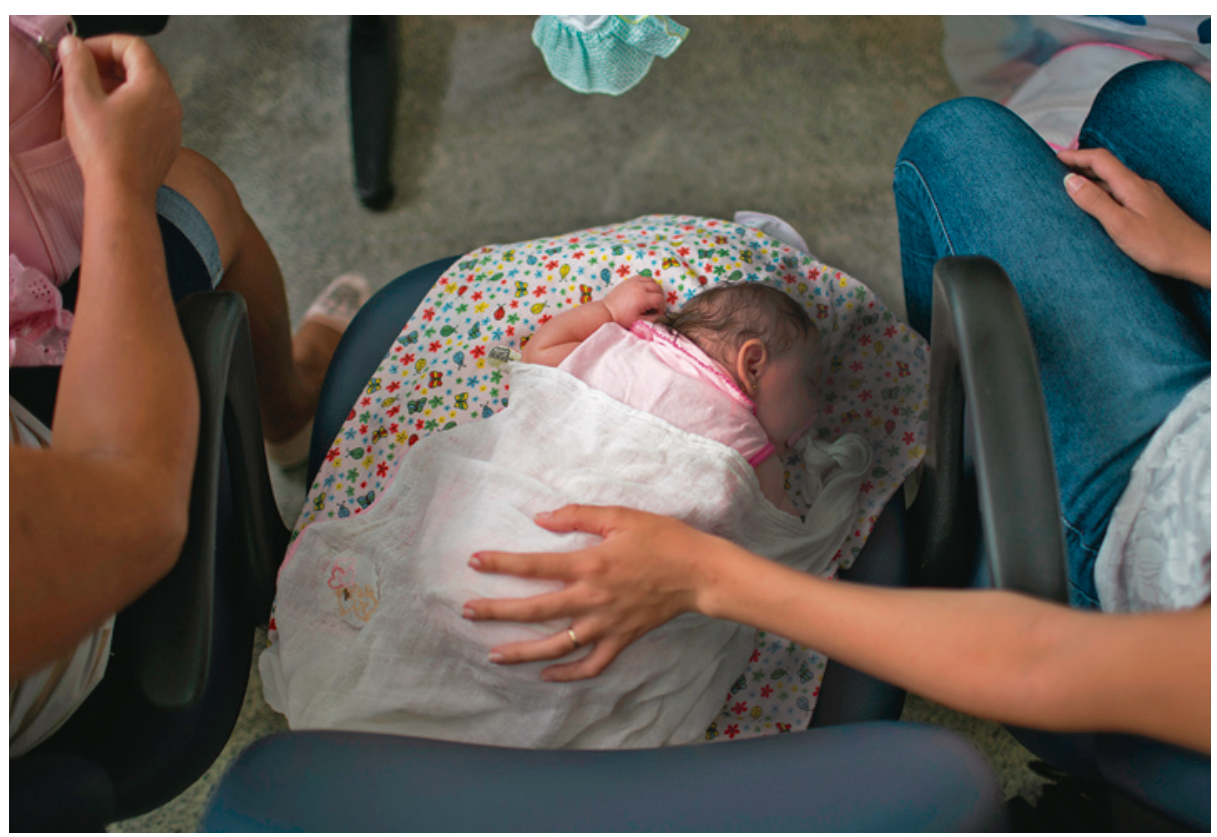

Illustrasjonsfoto: Felipe Dana/NTB scanpix

Zikaviruset ble første gang beskrevet i 1947 i Uganda, men først i 2007 ble det rapportert om større utbrudd forårsaket av zikavirus. Viruset er utbredt i store deler av Afrika, Asia og Oseania (1), men i løpet av det siste året er også store deler av Latin-Amerika blitt rammet (2). Dette utbruddet har særlig vakt oppsikt i Brasil, der det er antatt å være forklaringen på en dramatisk økt forekomst av mikrokefali hos nyfødte (2). Vanlige symptomer på zikavirusinfeksjon er feber, utslett, konjunktivitt, slapphet, leddsmerter og myalgi, tidvis med Guillain-Barrés syndrom som komplikasjon, men de fleste tilfellene er asymptomatiske (2).

Zikavirus smitter i første rekke gjennom bitt av Aedes-mygg, som det finnes flere arter av. I en fersk, senegalesisk studie har man testet vektorpotensialet til fire Aedesarter, og man fant at alle disse kan bli smittet, men at kun to av dem skiller ut viruset i spytt (3), noe som er en forutsetning for smitteoverføring. Smittepotensialet hos de testede myggartene var så lavt at forfatterne mener at andre vektorer kan spille en rolle i utbredelsen av zikaviruset, men flere arter ble ikke testet.
Zikaviruset kan sannsynligvis også smitte ved seksuell kontakt og blodsmitte, i tillegg til fra mor til barn (1). Potensialet for blodsmitte tilsier tiltak for å begrense smitte ved blodtransfusjon, spesielt $i$ land der viruset er utbredt, men også i andre land på grunn av mulighet for importerte tilfeller, noe som også har vært registrert i Norge (1).

\section{Kristoffer Brodwall}

kristoffer.brodwall@gmail.com

Institutt for global helse og samfunnsmedisin Universitetet i Bergen

\section{Litteratur}

1. Marano G, Pupella S, Vaglio S et al. Zika virus and the never-ending story of emerging pathogens and transfusion medicine. Blood Transfus 2015; 1-6. E-publisert 5.11. 2015.

2. Dyer 0 . Zika virus spreads across Americas as concerns mount over birth defects. BMJ 2015;351: h6983. doi: 10.1136/bmj.h6983 PubMed

3. Diagne CT, Diallo D, Faye 0 et al. Potential of selected Senegalese Aedes spp. mosquitoes (Diptera: Culicidael to transmit Zika virus. BMC Infect Dis 2015; 15: 492. doi: 10.1186/s12879-015-1231-2 PubMed

Publisert først på nett. 